OSOBA I DUSZA

Filozofia Chrzé́cijańska • Tom 7, Poznań 2010

Uniwersytet im. Adama Mickiewicza • Wydziat Teologiczny

MARCIN JIERS

\title{
Podstawa antropologiczna w koncepcji teologii Karla Rahnera
}

Anthropological Foundation in Karl Rahner's Concept of Theology

Mówienie o Tajemnicy dostępnej w doświadczeniu człowieka jako egzystencjalnej dialektyce Boga i człowieka, domaga się zwrócenia szczególnej uwagi na samego człowieka - stąd ,antropocentryczny zwrot" (anthropozentrische Wendung ${ }^{1}$ ). Jest to zwrot ku problemowi człowieka wraz z całym spektrum udzielanych na niego odpowiedzi, pozostających w centrum mówienia o Bogu. Zwięzłą i trafną charakterystykę metody Rahnera podaje wybitny dogmatyk A. Ganoczy:

Pod względem teoriopoznawczym poszukuje on przy każdym temacie dogmatycznym czynników umożliwiających jego rozumienie we właściwościach ludzkiej duchowości. W związku z tym Rahner mówi o, objawieniu transcendentalnym', które porusza się w sferze tego, co ,implicite nieświadome', zanim jako ,objawienie kategorialne’ zawładnie wyraźną świadomością człowieka. Bóg bowiem, który już jako ukryty zwraca się ku człowiekowi - niezależnie od tego, czy jest on chrześcijaninem, czy niechrześcijaninem albo nawet humanistycznym ateistą - daje się zasadniczo poznać na drodze tego, co niewypowiedziane, ku temu, co wypowiedziane, tego, co niewyraźnie wyczuwalne, ku temu, co jasno uświadomione, tego, co przedrefleksyjne, ku temu, co rozwinięte drogą refleksji. ,Prehistoria’ poznania Boga łączy w sobie

\footnotetext{
${ }^{1}$ Mówienie o Bogu zawiera w tle problem antropologii, pytającej człowieka o sposób rozumienia siebie, własnego bycia jako tego, który doświadcza siebie samego w ramach egzystencji, ogarniającej coś więcej niż tylko bycie różnym od innych stworzeń. O nowej strukturze tego rodzaju filozofii religii pisze B. Welte, Heilsverständnis, Freiburg 1966; tenże, Auf der Spur des Ewigen, Freiburg 1965; tenże, Religionspfilosophie, Freiburg 1978, wyd. pol. Filozofia religii, thum. G. Sowinski, Kraków 1996.
} 
wszystkie warunki, aby przyjąć z wdzięcznością historię Jezusa Chrystusa, tzn. w całej wyrazistości ,kategorialne’ samoobjawienie się Boga².

Dotychczasowy sposób myślenia ukształtowany przez kulturę umysłową średniowiecza, proponuje mówienie o Tajemnicy bez mówienia o człowieku. Taki sposób podejmowania refleksji nie brał pod uwagę tego, kim i czym jest sam człowiek, w jego konstrukcji poznawczo-wolitywnej, wraz z całokształtem jego życia i wiary. $Z$ tego względu Rahner postulował, aby w próbie wyjaśniania wiary mówić o człowieku i Bogu. Nie ma Boga bez człowieka, ani człowieka bez Boga ${ }^{3}$, czego eksplikacją jest wydarzenie Chrystusa, jako spotkania Boga i człowieka - najwyższy przypadek bycia prawdziwym człowiekiem.

Antropologia Rahnera nazywana jest antropologią transcendentalną ze względu na szczególną relację człowieka do Boga ${ }^{4}$, przy czym człowiek rozumiany jest tu jako absolutna transcendencja ukierunkowana na Boga, co uniemożliwia przeciwstawienie paradygmatu antropologicznego paradygmatowi teologicznemu. Mówienie o człowieku i mówienie o Bogu stanowi jedną rzeczywistość, na którą można spoglądać z dwóch różnych perspektyw ${ }^{5}$. Rozumienie relacji człowieka do Boga wyznacza koncepcja teologii, w której Rahner oparł się na idei teologii transcendentalnej, przy swoistym rozumieniu kategorii transcendentalności wyznaczającej kierunek rozumienia relacji człowieka, jako bytu w świecie, do Boga. Sam Rahner tak pisze o swoim rozumieniu teologii:

Transcendentalny sposób stawiania pytania, niezależnie od obszaru przedmiotów, w którym występuje, ma miejsce wtedy, gdy i na ile postawione zostanie pytanie o warunki możliwości poznania określonego przedmiotu, istniejące w samym podmiocie poznającym. [...] Transcendentalny sposób stawiania pytania jest poprzez to nie tylko dodatkowym pytaniem w stosunku do pytania o pierwotnie $\mathrm{i}$ aposteriorycz-

${ }^{2}$ A. Ganoczy, Einführung In die Dogmatik, Darmstadt 1983, s. 168n. Cyt. za: H. Wegner, Dogmatyka, tłum. J. Zychowicz, Kraków 2007, s. 44-45.

${ }^{3}$ K. Góźdź, Teologia człowieka, Lublin 2006, s. 225.

${ }^{4}$ Nerwem tego rodzaju refleksji jest pierwotna jedność porządku natury i łaski. Polega ona na niewykluczaniu pojęcia łaski czy przesuwania pojęcia łaski poza obszar konkretnej egzystencji. Antropologia tego rodzaju nie pozostaje niewrażliwa na zagadnienia takie, jak kwestia interkomunikacji, miłości, odczucia bezsensu, śmierci czy niepojawiania się Boga „w” świecie, w pełni konfrontuje się z tym, co charakterystyczne dla naszych czasów m.in. „eschatologią” świeckiej utopii przyszłości, rozpoczynającej się epoki „hominizacji” środowiska, oraz planowej samomanipulacji człowieka (Selbstmanipulation), o których pisze Johannes B. Metz m.in. w Christliche Anthropozentrik. Cechą charakterystyczną takiego myślenia jest koniecznościowe wchodzenie w przestrzeń niepojętności (Unbegreiflichkeit).

${ }^{5}$ Odczyt wygłoszony na sympozjum teologicznym w Chicago, 31.3. 1966. Druk: K. Rahner, Schriften zur Theologie, Bd VIII, Einsideln 1967, s. 43-65, tłum. pol. „Znak” 21 (1969), n. 12, s. $1535-1551$. 
nie-empirycznie występujący przedmiot, lecz dopiero $\mathrm{w}$ takim sposobie stawiania pytań poznanie pierwotnego przedmiotu osiaga swoją pełną istotę. Poznanie siebie samego przez poznający podmiot jest zawsze także poznaniem metafizycznych (w sensie obiektywnym transcendentalnych) struktur samego przedmiotu 6

Widoczne jest tu odniesienie do definicji Kanta zawartej we „Wstępie” do Krytyki czystego rozumu:

[...] transcendentalnym nazywam wszelkie poznanie, które zajmuje się w ogóle nie tyle przedmiotami, ile sposobem poznawania przedmiotów, o ile sposób ten ma być a priori możliwy ${ }^{7}$ (według wyd. A: lecz zajmuje się naszymi apriorycznymi pojęciami przedmiotów [A11 n.]).

Cechą wspólną obu określeń jest zwrócenie uwagi nie tyle na przedmiot poznania, ale przede wszystkim na podmiot poznający wraz z jego apriorycznymi pojęciami przedmiotów. Ponadto wykazują one, że pewne przedstawienia „nie są [...] pochodzenia empirycznego" i dlatego pozostaje jedynie pytanie o możliwość obiektywnego i rzeczywistego odniesienia do przedmiotów poznania oraz o możliwość pomyślenia w sposób wolny od sprzeczności i aporii ${ }^{9}$. Ponadto Rahner odwołuje się za Kantem do tradycyjnego określenia prawdziwości jako zgodności (korespondencji) pomiędzy myśleniem a przedmiotem, pokazuje zgodnie z kopernikańską rewolucją, że sposób stawiania pytania nie jest od podmiotu czymś niezależnym, czymś samym w sobie, lecz że jest dopiero konstytuowany za sprawą apriorycznych warunków poznającego podmiotu ${ }^{10}$.

${ }^{6}$ K. Rahner, Schriften zur Theologie, Bd IX, s. 98n. Cyt.za: I. Bokwa, Wprowadzenie do teologii Karla Rahnera, Tarnów 1996, s. 65-66. Termin ,transcendencja” ma tu znaczenie dynamiczne - chodzi tu o akty istoty duchowej, które przenoszą ją stale poza samą siebie w jej przyszłość, tj. w stan egzystencji człowieka, który osiaga dojrzałość w wolności. Rahner po raz pierwszy używa pojęcia „transcendentalny”w swoim dziele zatytułowanym Geist in Welt. Zur Metaphysik der endlichen Erkenntnis bei Thomas von Aquin, Innsbruck 1939.

${ }^{7}$ I. Kant, Krytyka czystego rozumu, B 25, tłum. R. Ingarden, Kęty 2001, s. 68.

${ }^{8}$ Tamże, B 81, s. 101.

${ }^{9}$ Według Kanta istnieją dwa źródła poznania, które posiadają być może jedno wspólne źródło, są nimi zmysłowość i intelekt (por. Krytyka czystego rozumu, s. 90). Poznanie nasze, według Kanta, wypływa z dwóch źródeł umysłu, pierwszego przyjmowania przedstawień (odbiorczość wrażeń) i drugiego zdolność poznania przedmiotu przez te przedstawienia - samorzutność pojęć (Por. Krytyka czystegorozumu, s. 138). W tak rozumianej strukturze poznania źródłem doświadczenia są wrażenia, a pewność i konieczność pochodzi z apriorycznych form poznania, na poziomie zmysłów (czas i przestrzeń) oraz apriorycznych pojęć, znajdujących się na poziomie intelektu. Pojęcia stanowią podstawę dla operatywności dedukcji transcendentalnej, która prowadzi do rozpoznania apriorycznych warunków możliwości doświadczenia (por. Krytyka czystego rozumu, s. 194). Samo zaś pojęcie nie istnieje bez naocznych danych świadomości (por. Krytyka czystego rozumu, s. 194-195).

${ }^{10}$ Wielowarstwowa struktura poznania u Kanta prowadzi do refleksji nad zdolnością podmiotu poznającego od syntezy przedstawień do synopsji, czyli obejmowania w naocznym ujęciu da- 
Tym, co odróżnia myśl Rahnera od Kanta, jest wyjście poza wymiar horyzontalny (analiza zakresu przedmiotów ludzkiego poznania) w kierunku wertykalnym (transcendencji Boga) ${ }^{11}$. Stąd można mówić, że kategoria transcendentalności funduje nam możliwość mówienia o relacji Bóg-człowiekświat $^{12}$. Dzięki takiemu rozumieniu kategorii transcendentalności staje się możliwe Objawienie Boga ${ }^{13} \mathrm{w}$,,rzeczywistości, która jest dostępna bezpośredniemu doświadczeniu człowieka" ${ }^{14}$ i przyjęcie przez człowieka tego samoobjawienia się Boga.

nych doświadczenia zmysłowego, mającego swoje rozwinięcie w syntezie danych naoczności w pojęciu (por. Krytyka czystego rozumu, s. 201). Zdolność dokonywania syntezy wynika z samej struktury podmiotu. Podmiot stanowi transcendentalny warunek syntezy, która prowadzi do konieczności transcendentalnej apercepcji, tj. transcendentalnej jedności świadomości o charakterze koniecznym, w odróżnieniu od apercepcji empirycznej, od doświadczalnej jedności świadomości na gruncie Ja empirycznego o treści zmiennej i zależnej od aktualnego stanu świadomości (por. Krytyka czystego rozumu, s. 211 i O. Höffe, Immanuel Kant, thum. A.M. Kaniowski, Warszawa 2003, s. 64).

${ }^{11}$ Por. I. Bokwa, Wprowadzenie do teologii Karla Rahnera, s. 66.

${ }^{12}$ Por. K. Góźdź, Teologia czlowieka, s. 225.

${ }^{13}$ „Z perspektywy faktycznego chrześcijańskiego objawienia konkretna możność słuchania boskiego objawienia konstytuowana jest przez dwa momenty: poprzez duchową transcendentalność człowieka (jego «podmiotowość») i poprzez tejże łaskawe «wywyższenie» względnie «rozjaśnienie» (tak zwany «egzystencjał nadprzyrodzony») [...] Egzystencjał nadprzyrodzony nie oznacza nowej, dodatkowej możliwości, lecz jest wewnętrznym rozjaśnieniem samej duchowej podmiotowości, względnie transcendentalności, nie będąc z niej jako takiej uzyskiwalnym, możliwość słuchania objawienia może być rozważona z podstawowej konstytucji ludzkiego ducha" (K. Rahner, Słuchacz Słowa, thum. R. Samek, Kęty 2008, s. 24). W konsekwencji możemy wskazać, że podjęta charakterystyka niesie ze sobą następujące konsekwencje:

a) Bóg może się objawić w taki sposób, że wykracza poza wszelką interpretację religijnego usposobienia człowieka;

b) Transcendentalność człowieka - jego „podmiotowość” stanowi o niemożliwości antycypacji pełni prawdy;

c) Człowiek ma wewnętrzną otwartość na przyjęcie objawienia;

d) Człowiek może i musi przyjąc takie objawienie, będące słuchaniem samego Boga (zakładając jego nieprzewidywalność, tzn. objawienie, nie będące antycypowane w swej treści, potencjalną otwartość człowieka na nie i skłonność na przyjęcie go w momencie, w którym się dokonuje), co pozwala na uniknięcie postrzegania objawienia jako dialektycznego korelatu względem skończoności człowieka.

Bycie człowieka w takiej optyce jawi się jako wsłuchiwanie w orędzie Boga, będące wiecznym światłem i wiecznym życiem w kierunku otwierającym dla ludzi w łasce głębi żywego Boga. Konsekwencją tego jest odrzucenie wszelkich przeżyć nieskończoności (doświadczeń mistycznych), jak mówi Rahner, nocno - ekstatycznych (ek-stasis), w obrębie własnej skończoności, wykluczających możliwość objawienia w ludzkim słowie Bożego objawienia.

${ }^{14}$ K. Rahner, Geist in Welt, München 1957, s. 14. 


\section{ANALIZA OSOBY I JEJ PODMIOTOWOŚCI}

Pośród wielu zagadnień zawartych w pracach Karla Rahnera szczególne miejsce zajmuje refleksja nad człowiekiem i możliwością doświadczenia przez niego wiary w konkretnym momencie historii. Rahner kreśli wizję człowieka zdolnego do przyjęcia tego, co zapełnia pustkę, jaka jest w nim samym, bycie skończonym. Stawia człowieka w relacji do nieskończonej Pełni, Tajemnicy, która w perspektywach religijnych i teologicznych nazywa się Bogiem. Perspektywa życia człowieka wobec Transcendencji daje nadzieję na spełnienie w ramach bytu osobowego, w spotkaniu z Tym, który się objawił i swoją bliskością znosi unicestwiający wyrok nałożony na człowieka przez siebie samego, przez własną pustkę.

Spotkanie człowieka z Bogiem dokonujące się w akcie wiary, wyrażane w niezwykle ciemny i trudny sposób implikuje podstawową dla chrześcijaństwa tezę, że człowiek jest osobą i podmiotem ${ }^{15}$. Właściwa konotacja tych terminów może się ukazać jedynie w kontekście tych twierdzeń, które mówią o transcendencji człowieka, jego odpowiedzialności i wolności, jego dążeniu w stronę niepojętej Tajemnicy, doświadczeniu własnej przemijalności jako „byciu w świecie"16 uwikłanym w szereg relacji tak wewnętrznych, jak i zewnętrznych. Te wszystkie dookreślenia wyrażają prawdę o autentycznej osobowości i podmiotowości człowieka jako ducha w świecie, uzdolnionego do tego, by stać się słuchaczem Słowa Boga w ramach historii, co świadczy o wolności Boga i człowieka ${ }^{17}$.

Człowiek jako jednostka i jako część określonego systemu struktury społecznej doświadcza siebie na różne sposoby, na ogół jako efekt tego, co radykalnie różne od niego samego. Owo doświadczenie stanowi integralny czynnik w procesie weryfikacji tego, co zostało powiedziane o człowieku w ra-

${ }^{15}$ Por. K. Rahner, Podstawowy wyktad wiary, thum. T. Mieszkowski, Warszawa 1987, s. 27.

${ }^{16}$ K. Rahner, Geist in Welt, Munchen 1957, s. 406. Termin zaczerpnięty od M. Heideggera (In-der-Welt-Sein). Wiele terminów Heideggera zaczerpniętych jest z codziennego języka, którym nadał nową treść, podobnie jak to uczynił A.N. Whitehead, aby w ten sposób stworzyć dogodne narzędzie, służące wyrażeniu oryginalnej, filozoficznej koncepcji. Oprócz nadawania nowego sensu wyrażeniom zaczerpniętym z codziennego języka Heidegger, a za nim Rahner, zajmują się tworzeniem neologizmów w oparciu o rdzenie słowne współczesnego im niemieckiego języka. Przykładem takiego neologizmu, którym posługuje się niemiecki jezuita, zaczerpniętym od Heideggera, jest termin Gelichtetheit, który można przethumaczyć jako „świetlistość” czy „prześwietlenie” w odniesieniu do bytu, mającego zdolność poznania i bycia poznanym, (według przekładu Bogdana Barana). Ponadto Rahner w traktacie Hörer des Wortes stosuje wiele terminów synonimicznych wobec świetlistości. Są to: „podmiotowość” (Subjektivität) oraz „zrozumiałość bytu” (Seinsverständnis).

${ }^{17}$ Por. I. Bokwa, Wprowadzenie do teologii Karla Rahnera, s. 93. 
mach nauk szczegółowych, empirycznych, roszczących sobie prawo do rozkładania człowieka na czynniki pierwsze, jego analizy i pytania o to, co przyczyniło się do jego powstania i rozwoju. Jest to słuszne i winno przebiegać według ściśle określonych metod.

Człowiek jako bycie-w-świecie (Heidegger) jest zdolny do zanurzenia się w siebie samego, co jest różne od niebycia-już-w-świecie. Często owo patrzenie w głąb siebie obarczone jest doświadczeniem troski ze względu na swoją przeszłość, swoje owładnięcie światem i swoje współbytowanie z innymi. W wyniku tego człowiek ma możliwość doświadczenia siebie jako tego, który zaistniał przez coś radykalnie różnego od niego samego. Tym samym byt ludzki wymyka się wszelkim analizom roszczącym sobie prawo do mówienia o człowieku jako całości w ramach ograniczonych kompetencji poszczególnych nauk zajmujących się człowiekiem jako bytem wewnątrzświatowym ${ }^{18}$.

Swoisty charakter doświadczenia osoby ujawnia się w szczególności wtedy, kiedy człowiek odkrywa w sobie samym elementy konstytutywne, świadczące o jego tożsamości. Elementy te często podlegające myślowym odzwierciedleniom i całościowym ujęciom, stanowiące mowę jako taką, nie odzwierciedlają tego, co dane w milczących i nie narzucających się doświadczeniach ${ }^{19}$.

W akcie samointerpretacji człowieka może uaktywniać się trwoga związana z niechęcią do poznania prawdy znoszącej niewiedzę samego siebie, ze względu na to, że jest ona czymś więcej niż sumą tych wszystkich elementów podlegających analizie jako rzeczywistości stanowiącej o jego tożsamości. Z drugiej strony człowiek jako ten, który jest uzdolniony do stawania wobec siebie, pyta o siebie samego, co odróżnia go ze zbioru systemów skończonych i tym samym owym zapytaniem o siebie samego wykracza poza podmiotowość obiektywności, która jest efektem refleksji nauk o człowieku. Ta zdolność człowieka do zajmowania się samym sobą różnicuje w nim samym podmiotowość od jego przedmiotowości.

„Bycie osobą znaczy więc samoposiadanie podmiotu jako takiego w świadomej i wolnej relacji do całości" ${ }^{20}$. Kategoria samoposiadania zdaje się mieć swoje korzenie już u św. Tomasza, gdzie w Summa contra Gentiles omawia on rozumienie bytu w aspekcie podmiotowym - byt uczestniczy w istnieniu o tyle, o ile ma on konieczne odniesienie do samego siebie (super ipsum reflecitur $)^{21}$. Owa relacja człowieka do siebie samego jest byciem wobec siebie

\footnotetext{
${ }^{18}$ Por. K. Rahner, Podstawowy wyktad wiary, s. 29.

${ }^{19}$ Por. tamże, s. 30.

${ }^{20}$ Tamże, s. 31.

${ }^{21}$ Por. Tomasz z Akwinu, Summa contra Gentiles IV. 2. Odniesienie człowieka do bytu jest
} 
jako jednostki i całości. Samoposiadanie człowieka wykracza poza kategorialne doświadczenia i determinacje zewnętrzne oddziaływające na niego samego. Stanowi fundament możliwości zapytania o siebie samego i pytania o możliwość zapytania. Stąd wynika nieredukowalność podmiotowości człowieka do jakiejkolwiek danej w ramach ograniczonego systemu, jaki stanowi człowiek. Podmiotowość jako taka jest nieredukowalnym faktem egzystencji, obecnym w każdym kategorialnym doświadczeniu, jako dany uprzednio warunek. Dana podmiotowości i osobowości ograniczonego systemu daje możliwość mówienia o doświadczeniu transcendentalnym, w ramach którego wymyka nam się to, co rozumiemy poprzez podmiotowość i osobowość. Doświadczenie transcendentalne w pełni ujawnia się w ramach doświadczenia podmiotowości człowieka, a więc tam, gdzie pozostaje jako dany samemu sobie, przy możliwości samowyjaśnienia i samoanalizy.

\section{CZłOWIEK JAKO BYT TRANSCENDENCJI}

Właściwe znaczenie człowieka w relacji do Tajemnicy pełniej wyraża się poprzez określenie go jako bytu transcendencji, bytu duchowo-osobowego związanego koniecznie ze światem boskim ${ }^{22}$. Człowiek jako byt ograniczony, jako tajemnica połączenia ducha i materii, wyposażony w nadprzyrodzony egzystencjał, posiada naturalne pragnienie poznania Boga. Owo pragnienie poznania nabudowane na tajemnicy człowieka jest tym, co odróżnia człowieka od innych bytów naturalnych. Poznanie człowieka, uwzględniające jego strukturę materialno-duchową winno dokonywać się poprzez analizę relacji człowieka do Boga, wyrażającej jego wewnętrzne nakierowanie na Tajemni-

koniecznym odniesieniem do samego siebie. Intelekt ludzki poznaje jedynie poprzez zwrot ku obrazom pochodzenia materialnego (por. STh. I,84,7), lecz charakterystyczne jest także to, że proces poznania polega na przekraczaniu zmysłowości w procesie abstrakcji, w którym intelekt czynny (Akwinata w rozważaniach nad intelektem czynnym bazuje na propozycji Stagiryrty [zob. Arystoteles, De anima, III, 5 (430a 10-15)], włączając je w nurt rozważań o duszy, co zdaje się z punktu widzenia Tomasza współgrać z autorytetem Pisma św. - Ps 4,7) tworzy wyobrażenia, na bazie tego, co zawarte w zmysłach (por. STh., I,84,6). Poznanie intelektu stanowiącego formę substancjalną człowieka polega na dochodzeniu do siebie jako podmiotu poprzez wychodzenie od danych poznania zmysłowego do zrozumiałości siebie i rzeczy w ogóle (por. STh. I,87,1). Dynamizm poznania rozpiętego pomiędzy danymi zmysłowymi a możliwością zrozumienia samego procesu poznania jest nieograniczony i otwarty, co nie znaczy, że człowiek może poznać nieskończoność in actu, ale poznaje ją in potentia (por. STh. I, 86,2). Dla Tomasza człowiek jest nieskończonością negatywną, otwartością na nieskończoność (por. STh. I,78,1; I,80,1). Dwie właściwości człowieka, tj. transcendencja i „bycie-przy-sobie” w procesie poznania stanowią podstawę dla możliwości ujmowania człowieka w kategoriach podmiotowości.

${ }^{22}$ Rahner na określenie człowieka jako ducha stosuje formułę: Mensch als Geist. 
cę Boga. Można zatem mówić o Bogu jako możliwości danej samemu człowiekowi. Tajemniczość człowieka i jego uczestnictwo w relacji do Boga zostało w pełni wyrażone poprzez Słowo Boga, które stało się ciałem ${ }^{23}$. Człowiek stał się możliwością dla wypowiedzenia Słowa samego Boga. Został wewnętrznie usposobiony do usłyszenia i przyjęcia Słowa. Poprzez to spotkanie została ustanowiona nierozdzielność pomiędzy samo-wypowiedzeniem Słowa Bożego, jego usłyszeniem i przyjęciem. Ponadto została ukonstytuowana sama tajemnica spotkania Absolutu z człowiekiem i konieczność poszukiwania Boga i Jego woli przez człowieka, co należy do podstawowego doświadczenia egzystencji. Owo doświadczenie jest nieustannym dostrzeganiem rozszerzającej się rzeczywistości, w której to człowiek uczestniczy poprzez „otwieranie się nieskończonego horyzontu bytu” ${ }^{24}$, co wprawia go w ruch i podtrzymuje w tym ruchu. Ostatecznie tym, co wprawia człowieka - podmiot nieabsolutny - w ruch, jest możliwość podejmowania decyzji zgodnie z własną wolą, doświadczana przez skończoność i przypadkowość. Zarazem w samym człowieku zostaje potwierdzona niemożliwość przezwyciężenia niemożności rozporządzania własną egzystencją²5.

Samodoświadczenie człowieka jest możliwe wtedy, gdy jest bytem nieustannie nakierowanym na kogoś lub coś drugiego w obrębie świata rzeczy, przy uwzględnieniu tego, od czego on sam pochodzi, a będącego radykalnie różnym od niego samego, nie będącego bytem skończonym, stanowiącym zasadę spójności i zupełności wszystkich możliwych konfiguracji opierających się na połączeniu bytów indywidualnych i wszystkich poszczególnych indywiduów jako ogół rzeczy jednostkowych i zróżnicowanych względem siebie.

Doświadczenie transcendentalności stanowi podstawową sytuację egzystencjalną, w której człowiek wykracza poza każde doświadczenie przedmiotowe. „Doświadcza apriorycznej otwartości podmiotu na byt w ogóle”, przy

${ }^{23}$ Schemat, jakim operuje Rahner, w literaturze nazywany jest Grundaxiomem i oznacza ,podstawową zasadę" mówienia o Trójjedynym Bogu. Zasada ta opiera się na założeniu, że Trójca ekonomiczna jest Trójcą immanentną - Bóg jawi się w świecie jako ten, który ofiaruje człowiekowi udział w swoim wewnętrznym życiu. Życie Boga staje się udziałem stworzenia na drodze trynitarnego samoudzielania się Boga. Przez ten zabieg Rahner dokonał wprowadzenia dyskursu o Bogu w ramy chrześcijańskiej soteriologii. Krytycy tego projektu zarzucają Rahnerowi zbytnią ufność względem dialektycznej metafizyki Hegla, opierającego się na próbie spójnego i syntetycznego powiązania rzeczywistości stworzonej z rzeczywistością samego Boga. Wiązanie to dokonuje się w obrębie dialektycznego procesu, w którym Bóg staje się sobą, do siebie dochodzi, poprzez pośrednictwo świata stworzonego (por. Hegel, Wykłady z filozofii religii, II, tłum. Ś.F. Nowicki, Warszawa 2007, s. 215, 224-225).

${ }^{24}$ K. Rahner, Podstawowy wyktad wiary, s. 34.

${ }^{25}$ Tegoż, Laska i natura, w: tenże, H. Vorgimler, Mały słownik teologiczny, thum. T. Mieszkowski, P. Pachciarek, Warszawa 1987, kol. 215. 
uwzględnieniu każdego doświadczenia kategorialnego, stanowiącego fundament wszelkiej obiektywizacji. Przez obiektywizację rozumie się tu sposób porządkowania, w którym następuje przyporządkowanie konkretnych indywiduów do nadrzędnego układu rzeczowego. Dzięki temu zyskuje się dostęp do tego, co szczegółowe wychodząc od tego, co najogólniejsze ${ }^{26}$. Ponadto należy zauważyć, że zbiór kategorialnych obiektywizacji jest możliwością ujawnienia-doświadczenia transcendencji, przy czym w żadnym razie jej nie wyczerpuje. Tak więc człowiek, będąc bytem transcendencji, zostaje rzucony w przestrzeń tajemnicy oznaczającej niepoznawalną i niewyrażalną rzeczywistość, dającą możliwość otwarcia na nieskończony horyzont bytu i tym samym daje możliwość stawania przed samym sobą jako osobą i podmiotem ${ }^{27}$. Podsumowując należy stwierdzić, że bycie człowiekiem polega na transcendowaniu siebie samego. Jak mówi sam Rahner, ,człowiek jest, na ile istnieje ponad siebie" 28 , w stronę Tajemnicy dającej możliwość stawania się sobą. Owo istnienie ponad siebie jako „stała egzystencja" ${ }^{29}$ znajduje się w strukturze człowieka i doświadczana jest a priori i współwystępuje pośród innych doświadczeń transcendentalnych. Stanowi fundament możliwości mówienia o człowieku w ramach teologii i antropologii.

\section{WOLNOŚĆ I ODPOWIEDZIALNOŚĆ PRZESTRZENIA DOŚWIADCZENIA TRANSCENDENCJI}

W ramach filozoficzno-teologicznej refleksji Karla Rahnera ${ }^{30}$, opierającej się na metodzie transcendentalnej, ujawnia się problematyka antropologii metafizycznej wraz z jej częściami składowymi: pytaniami o sens i warunki doświadczenia wolności i odpowiedzialności człowieka.

Wolność i odpowiedzialność, według Rahnera, to kategorie składowe zbioru egzystencjałów ludzkiego istnienia. Do istoty pojęcia wolności należy

${ }^{26}$ Por. M. Heidegger, Fenomenologia życia religijnego, thum. G. Sowinski, Kraków 2002, s. 57.

${ }^{27}$ Por. K. Rahner, Podstawowy wyktad wiary, s. 35.

${ }_{28}$ Tegoż, Hörer des Wortes, München 1941, s. 45.

${ }^{29}$ A. Kuśmierski OP, Poznanie Boga wedtug transcendentalnej metody Karla Rahnera,

http://www.teofil.dominikanie.pl/test/index.php/content/view/345/119/, 1.19.2010.

${ }^{30}$ Podstawowe kierunki, które wyznaczają linię interpretacyjną koncepcji antropologii metafizycznej, a w jej zakresie pojęcia wolności, wywodzą się od transcendentalnych podstaw filozofii św. Tomasza, biegnącej przez kantyzm i jego interpretacje aż do reinterpretacji myśli św. Tomasza, dokonanej na bazie refleksji Kanta, proponowanej przez Maréchala, rozwijanej na gruncie myśli egzystencjalnej Heideggera, dają możliwość pewnego wspólnego modelu ontologii i metafizyki ludzkiego poznania, przy uwzględnieniu całej różnorodności tych systemów, zarówno w zakresie terminologii, jak i przyjętych metod. 
to, że wymyka się ona przyporządkowaniu kategorialnemu, nie stanowi ona jednej z wielu sprawności człowieka uczestniczących w momencie decyzyjnym $^{31}$. Ponadto daje możliwość wychylenia człowieka ku temu, co wieczne. Według Rahnera,

wolność jest przede wszystkim odpowiedzialnością podmiotu wobec samego siebie, tak że w swojej najgłębszej naturze dotyczy podmiotu jako takiego i w jego całości ${ }^{32}$.

Wolność pozbawiona jest charakteru temporalnego. Dąży do tego, by stawać się chwilą aktualną samej wieczności, tj. trwania pozbawionego następstwa czasu. Wolność jest dla człowieka momentem próby, w którym usiłuje on zespolić wszelkie możliwe akty czasowości w jedną i całą aktualność egzystencji zawierającej to, co wcześniej i to, co później. Należy jednak zauważyć, że czyn wynikający z wolności - wolne działanie - jest jednak działaniem historycznym, co pozwala określić człowieka jako skończonego ducha ze względu na jego otwarcie na nieskończoną Tajemnicę w ramach własnego bytu materialnego ${ }^{33}$. Ponadto warto zaznaczyć, że historia jest wszędzie tam, gdzie jest wolny czyn. Wynika to z ogólnej charakterystyki danych dotyczących określonej rzeczywistości metafizycznej ${ }^{34}$.

Moment wolności zawsze dotyczy całości egzystencji, za którą człowiek jest odpowiedzialny. Przejście od wolności chwili do całości życia napotyka właściwe sobie aporie m.in. wtedy, gdy akt wolności niedostatecznie sięga głębi egzystencji oraz wtedy, gdy człowiek nie jest dostatecznie wolny w swoim działaniu, określającym jego samego ${ }^{35}$ jako coś jednego, stanowiącego określoną całość. Wolność zatem ujawnia się jedynie w układzie przestrzenno-czasowym, przy uwzględnieniu linearnego procesu dziania się, w którym człowiek ma możliwość stawania się niezależnym od siebie samego. Wolność stanowi warunek zaistnienia pojedynczych aktów i wydarzeń składowych w obrębie całego życia.

W akcie wolności spełnia się samoaktualizacja podmiotu, która zostaje przefiltrowana przez pośrednictwo danych czynów jako przejawów ludzkiej

\footnotetext{
${ }^{31}$ Wbrew dociekaniom m.in. Josefa Fuchsa, który wychodząc z założeń Rahnera nie potrafił zachować absolutnych norm moralnych, uciekając w przestrzeń moralności i etyki sytuacyjnej.

${ }^{32}$ K. Rahner, Podstawowy wyktad wiary, s. 82.

${ }^{33}$ Określenie człowieka jako ducha oznacza, że wiedzie on swoje życie w nieustannym sięganiu ku Absolutowi, w otwartości na Boga. Tożsamość człowieka, to, kim jest i kim się staje, przebiega według dynamizmu zmierzania ku Bogu, choćby w sposób nieokreślony pojęciowo. Człowiek jest nieskończoną otwartością skończonego na Boga.

${ }^{34}$ Por. K. Rahner, Stuchacz słowa, thum. R. Samek, Kęty 2008, s. 101.

${ }^{35}$ Por. tenże, Modlitwa i wiara, tłum. G. Sowinski, Kraków 2000, s. 86.
} 
aktywności. Tym samym konstytuuje bycie-w-świecie pojedynczego podmiotu w nienaruszalności jego historii.

Człowiek jako byt wewnątrzświatowy obdarzony jest wolnością, nie dającą się zredukować do jakiegokolwiek elementu mającego stałe zastosowanie przy zmiennych okolicznościach. W dodatku próba określenia tego, czym jest wolność, według Rahnera, prowadzi do określenia wolności w kontekście relacji człowiek - Tajemnica, rozumiana jako najwyższa wartość, jako możliwość dopełniania ku temu, co ostateczne, ku czemu wychylony jest człowiek w swoim celowościowym dążeniu, poprzez pośrednictwo Tajemnicy w swojej egzystencji dla pojmowania Tajemnicy poza sobą. Pomimo tego wolność nie stanowi stałej dyspozycji wyrzucającej nas w przestrzeń nieskończoności. Stanowi jedynie możliwość bycia człowieka ku wieczności. Próba określenia tego, czym jest wolność w kontekście wieczności, ujawnia nam przestrzeń, w której to Tajemnica udziela swojej wieczności za pośrednictwem wolności, w ramach czasowości i zmiennej egzystencji człowieka. Jest czynnikiem utożsamiającym egzystencję, dając jej możliwość konstytuowania się w nas samych wieczności wraz z jej dynamicznym charakterem. Dynamizm ten uwarunkowany jest przez egzystencję człowieka, jego wieczność i stawanie się wiecznością.

Wolność odnosi się do całości ludzkiej egzystencji. Owa całość dotyczy relacji zróżnicowania i zgodności oraz tego, kim człowiek jest i kim nie jest. W odkrywaniu wolności w ramach egzystencji, człowiek doświadcza siebie jako istoty uwarunkowanej, podlegającej wpływom zewnętrznym i wewnętrznym. Stąd można mówić o koegzystencji wolności i konieczności w życiu człowieka. Stosunek człowieka do bytu, jako podstawa wszelkiego poznania, jako pryncypium odkrywania, wspierające i porządkujące relacje poznającego do poznawanego, stanowi przestrzeń, w której odkrywam swoją wolność i doznaję konieczności. W tej relacji aktywny podmiot czyni przedmiot poznania swoim i tym samym przejmuje za niego odpowiedzialność. Wszelkie przejawy aktywności człowieka ukierunkowane w stronę świata, ujawniają złożoność z dwóch różnych substratów wolności i konieczności. Kant, do którego Rahner chętnie się odwołuje, wskazuje, że

wolność przypisana woli stoi w sprzeczności z koniecznością przyrody, a rozum na tej rozstajnej drodze uważa, że z teoretycznego punktu widzenia droga konieczności przyrodniczej jest o wiele bardziej utarta i użyteczna niż droga wolności, to jednak z praktycznego punktu widzenia ścieżka wolności jest jedyną, na której jest możliwe posługiwanie się w swym postępowaniu własnym rozumem ${ }^{36}$. I dalej: wolność i ko-

\footnotetext{
${ }^{36}$ Tamże s. 100
} 
nieczność nie tylko bardzo dobrze mogą razem istnieć, ale także muszą być pojęte jako koniecznie połączone w tym samym podmiocie. Inaczej bowiem nie można by uzasadnić, dlaczego mielibyśmy rozum obarczać ideą, która, choć da się połączyć bez sprzeczności z inną dostatecznie sprawdzoną, jednak wikła nas w sprawę, która rozumowi w teoretycznym jego użyciu bardzo wiele sprawia kłopotu ${ }^{37}$.

Stąd rodzi się aporia w uzgadnianiu tego, co dane w subiektywnym odczuciu z obiektywną sytuacją, względem, której ujawniła się ludzka aktywność, świadcząca o wolnym podmiocie. Wolny podmiot pozostaje niezależny od siebie samego poprzez pośrednictwo rzeczywistości obiektywnej, która staje się możliwością powrotu do siebie samego, stanowi punkt wyjścia i dojścia, stanowi funkcje pośrednictwa pomiędzy człowiekiem a właściwym „przedmiotem” wolności ${ }^{38}$.

${ }^{37}$ Tamże s. 101.

${ }^{38}$ Mówienie o wolności u Kanta winno uwzględniać tożsamość rozumu praktycznego z wolną wolą. W rozdziale z pierwszej Krytyki, mówiącym o antynomiach Kant, wskazał, że pojęcie wolności transcendentalnej jest w ogóle możliwe do pomyślenia. Zasada autonomii z drugiej Krytyki pokazuje, że wolność transcendentalna jest pojęciem negatywnym, na które można spojrzeć od strony pozytywnej, by dostrzec w niej ściśle określoną wolność moralną. Ponadto Kant wskazuje na rzeczywistość moralnego wymiaru wolności. Należy zaznaczyć, że refleksje Kanta dotyczące wolności rozpatrywane są w kontekście filozofii prawa, filozofii dziejów, fillozofii religii. Tym, co odróżnia myśl Rahnera od Kanta w kwestii wolności, to wyjście poza wymiar horyzontalny (analiza zakresu przedmiotów ludzkiego poznania) w kierunku wertykalnym (transcendencji Boga). Stąd można mówić, że kategoria transcendentalności funduje nam możliwość mówienia o relacji Bógczłowiek-świat na fundamencie pojęcia wolności. Dzięki takiemu rozumieniu kategorii transcendentalności staje się możliwe objawienie Boga w rzeczywistości, która jest dostępna bezpośredniemu doświadczeniu człowieka i przyjęcie przez człowieka tego samoobjawienia się Boga, wzywającego podmiot doświadczenia do wolności. Człowiek dla Rahnera jest bytem wolności, bytem samourzeczywistniającym się w relacji do drugiego. Relacyjna struktura wolności odnosi podmiot do rzeczywistości poza nim samym. (por. K. Rahner, Stuchacz słowa, s. 76-96). Wolność dla Rahnera jest cechą charakterystyczną ducha ludzkiego czy człowieka określanego mianem ducha. Człowiek w akcie poznania i woli odnosi się w sposób konieczny do Boga. Kant w swoich rozważaniach nie podejmuje zagadnienia odniesienia do Boga, rozważając pojęcie wolności. Wskazuje na pojęcie cnoty, będącej czymś wewnętrznym, nie będącej czymś możliwym do doświadczenia, nie mówi o tym w kontekście wolności. Relacyjność wynikająca z faktu wolności łączy się bezpośrednio z procesem poznania, w którym to człowiek doświadcza siebie jako bytu skończonego. Podstawą odniesienia do siebie samego, według Rahnera jest wola, „to konieczne, absolutne ustanowienie [...] jest dlatego wola. U podstawy konkretnego bytu ludzkiego, pośrodku pierwszej transcendencji w kierunku bytu ma miejsce (konieczny) czyn woli. Otwarcie bytu jako takiego na konkretny byt ludzki jest sprawione przez wolę jako wewnętrzny moment samego poznania” (cyt. za: I. Bokwa, Wprowadzenie go teologii Karla Rahnera, s. 103). Wolność jest zatem podstawowym atrybutem natury człowieka. Ponadto należy wskazać, że Rahnerowi bardzo zależy na wykazaniu łączności pomiędzy pojęciem wolności i absolutu. Ludzka, skończona wolność jest w sposób konieczny nakierowana na Boga, dzięki posiadaniu intelektu czynnego (intellectus agens) człowiek jest zdolny poznać byt. Realizacja siebie samego w akcie wolności potwierdza fakt, że człowiek jest zdolny do tego, by poznać byt. Wolność jest naśladowaniem wolności Boga: człowiek doświadcza, że jest 
Uczeń Rahnera, Herbert Vorgrimler ${ }^{39}$, analizując pojęcie wolności ${ }^{40}$ wskazuje na jej wymiar osobowy, a czyni to poprzez rozróżnienie wolności pozytywnej i negatywnej. Wolność pozytywna, powiada ten autor, jest wolnością „do czegoś” lub „do kogoś”, natomiast wolność negatywna jest wolnością wyboru, gdzie moment decyzyjny jest równoznaczny z możliwością wyboru czegoś i jednocześnie odrzucenia innej z rozpatrywanych możliwości. Bez wątpienia dokonane rozróżnienie potwierdza całe tło nakreślone przez Rahnera - rozumienie wolności dokonuje się poprzez widzenie człowieka jako bytu transparentnego, $\mathrm{tj}$. transcendentnego i otwartego na Transcendencję. Dlatego wolność sytuuje w przestrzeni wolności decyzji ${ }^{41}$, gdzie jej podmiotem jest duchowa osoba. Wolność dla duchowej osoby, tj. osoby otwartej na nieskończonego Boga, pełni możliwość aktualizacji potencjalności bytowej, umożliwia mu dojście do samoposiadania. Wyrywa go poza trwanie pomiędzy „tak” lub „nie” wobec Tajemnicy ${ }^{42}$. W akcie wolności każde kategorialne doświadczenie stanowi możliwość zajęcia konkretnego stanowiska wobec samego Boga, funduje człowiekowi możliwość zajęcia postawy wobec Niego, gdzie każde „nie” jest nierówne jakościowo wobec „tak”, a to ze względu na to, że „nie" wypowiedziane jako orientacja całej egzystencji człowieka wobec Absolutu jest ustanowieniem kategorialnego celu do rangi absolutnego, i następnie w sposób absolutny mierzy miarą celu kategorialnego cały zakres doświadczanych rzeczywistości, w opozycji do bezwarunkowego trwania wobec niewyrażalnej Tajemnicy, którą to nie my rozporządzamy, ale dajemy się jej owładnąć. Każde „nie” wypowiedziane w akcie decyzyjnym człowieka wobec Absolutu stanowi alternatywę wobec „tak”. Jednak owo „nie” nie jest

niesiony wolna moca czystego bytu. Bóg istnieje na sposób osobowy - człowiek pozostaje nieustannie w relacji do osobowego Innego, gdyż jest wolny i pozwala się poznać. Związek człowieka z Bogiem, związek dwóch niewykluczających się wolności jest udziałem człowieka w wolności samego Boga, co gwarantuje możliwość zrozumienia tego, kim jest człowiek dla niego samego jako pytającego, czym jest wolność i jego istota.

${ }^{39}$ Urodzony w roku 1929 we Fryburgu, doktoryzował się w roku 1958 u K. Rahnera. Od roku 1968 profesor dogmatyki na Wydziale Teologicznym na Uniwersytecie w Lucernie. W roku 1972 profesor dogmatyki i historii dogmatów na uniwersytecie w Münster. Był sekretarzem i współpracownikiem Rahnera.

${ }^{40}$ H. Vorgrimler, Neues Theologisches Wörterbuch, s. 197.

${ }^{41}$ Por. K. Rahner, Die Freiheit in der Kirche, w: Schriften zur Theologie, Bd II, Ensiedeln 1970, s. 96.

${ }^{42} \mathrm{Na}$ marginesie wypowiedzi II soboru watykańskiego Rahner twierdzi, że możliwość zaprzeczenia istnienia czy poznania Boga jest, jak się zakłada, postawą działającą zgodnie z własnym sumieniem, szukającą prawdy, spełniającą wymogi poczucia moralnego danego człowieka. Wobec powyższego, czy jest możliwy rzeczywisty ateizm, który nie jest ukrytym anonimowym teizmem? A jeżeli jest możliwy, to czy nie należałoby szukać pewnej pozytywności w owym „nie” jako sposobie rozjaśniania sensu bytu w ogóle? 
równe jakościowo z „tak” - „nie” istnieje o tyle, o ile istnieje „tak”. Tylko poprzez wstępne rozumienie możliwości powiedzenia „tak” mamy dostęp do możliwości wypowiedzenia „nie”. Wynika stąd, że „nie” jest wtórne wobec „tak”. Każde „nie” jako odpowiedź człowieka na proces uczestniczenia w „dokąd” i „skąd” transcendencji stanowi sprzeczność samą w sobie, a to ze względu na zaprzeczenie temu, co konstytuuje naszą możliwość wolności i tym samym możliwość wypowiedzenia „tak” lub „nie”43.

Wolność jest możliwością realizacji siebie jako tego, kto jest obdarzony godnością i pozostaje w relacji do Boga oraz do drugiego człowieka. Godność człowieka zasadza się na wolności. To życie w otwartej przestrzeni możliwości daje szansę „czynienia siebie samego"44. Człowiek jest bytem żyjącym w określonej przestrzeni, w którą wnosi swój własny zasób istotowy wraz z możliwością kreacji samego siebie. Owa możliwość sugeruje, że człowiek jest zdolny do deformacji jestestwa - może wikłać się w układ tego, co dysponuje nim samym. Stąd powstaje możliwość mówienia o różnych stopniach bycia wolnym i nie-wolnym. Tworzenie siebie samego jest tu dążnością podstawy do określonej samowiedzy, danej w doświadczeniu tego, co sięga poza niego samego. Podstawa czynienia siebie samego jest możliwością sięgania po głębie tęsknoty i po najwyższe przestrzenie ducha, a jej zaprzeczenie to wikłanie się i ograniczanie horyzontu bycia wyłącznie do egzystencjalnej nieważności ${ }^{45}$. Owa dążność oznacza, że człowiek w akcie wolności nigdy nie dysponuje do końca samym sobą. Wyraża to faktualność charakterystyczną dla zakresu egzystencji i tego, co w niej stłumione, świadczące o charakterze bycia jestestwa „tu oto"46. Realizacja wolności w akcie stawania się sobą polega na wyborze jednej z danych możliwości, sprostaniu temu, że nie wybraliśmy innych i wybrać ich nie możemy. W siatce relacji stawania się sobą, w akcie wolności jako bytu otwartego na to, co radykalnie różne od niego samego a możliwością zaprzeczenia sobie poprzez nierealizowanie wolności, tkwi z istoty możliwość unieważnienia siebie. Owa możliwość unieważnienia siebie świadczy wobec tego o możliwości zaistnienia jestestwa obarczonego wina. Wina, jako efekt swoistego napięcia pomiędzy możliwością realizowania wolności a jej zaprzeczeniem, staje się podstawą

${ }^{43}$ Por. K. Rahner, Podstawowy wyklad wiary, s. 89. Na gruncie filozoficznym, zgodnie z intuicjami Rahnera, problem możliwości wypowiedzenia Bogu „nie” zostaje analizowany w pracy B. Welte pt. Filozoficzne poznanie Boga a możliwość ateizmu, a na gruncie teologicznym J.B. Metz'a, Niewiara jako problem teologiczny.

${ }^{44} \mathrm{~K}$. Rahner, Würde und Freiheit des Menschen, w: Schriften zur Teologie, Bd II, Ensiedeln 1970, s. $247-277$.

${ }^{45}$ Por. M. Heidegger, Bycie i czas, thum. B. Baran, Warszawa 1994, s. 401.

${ }^{46}$ Por. tamże, s. 192. 
nie-ważności jestestwa. Owa wina nie świadczy o niezrealizowanym projekcie, będącym egzemplifikacją tego, co dane w świadomości, ale sam sposób bytowania w świecie, jako zdolność zachowania niezależności od tego, co ma moc zniewalania, ale i zdolność do bycia nieowładniętym przez to, co sam z siebie jestem w stanie zaprojektować jako układ potencjalnych możliwości i tego, co już staje się projektowaniem. Wolność jest swoistym „przejściem” w stronę bytu i jego aktywności. Dzięki niej zostaje wyrwany z przymusu, z biernego poddania się układowi rzeczy oddziaływających na niego i może dokonywać wyboru pomiędzy „tak” czy „nie” wobec zastanej rzeczywistości. To wolność nadaje kształt egzystencji człowieka, nadaje kierunek działania i wyznacza ostateczne „dokąd” wszelkich jego kategorialnych poczynań, ustanawiających relację do Boga i drugiego człowieka. Dzięki wolności człowiek jest rozpięty pomiędzy heroizmem a bestialstwem wtedy, kiedy „,wolność pragnie sobie złupić i panem być na własnej pustyni”" ${ }^{37}$ i wtedy, gdy staje się wolny od wszelkiego rodzaju przekonań. Tak więc fakt wolności, bycia wolnym wyjaśnia dążenie człowieka do dobra, do religijności, do znoszenia trwogi z obawy przed utrata posiadanego dobra i w końcu ,niepamiętania” o własnej śmierci, przemijalności, możliwości zerwania więzi wydarzenia śmierci Jezusa ze śmiercią własną i zwrotu od Tajemnicy do absolutyzacji dobra względnego. Wreszcie wolność jest tym, co wyrywa nas z czystego determinizmu warunkowanego poprzez relację przyczyna-skutek, z racji wolności - teraz nie możemy znać swoich działań przyszłych ${ }^{48}$, dzięki czemu nasza wolność staje się możliwością czynienia siebie, przy jednoczesnym ograniczeniu polegającym na pozbawieniu władzy nad tym, co przyszłe. Stawia to człowieka $\mathrm{w}$ jego bezgraniczności istnienia w relacji do Boga, do przyszłości, gdzie Bóg stanowi przyszłość, a przyszłość niekoniecznie stanowi Boga $^{49}$, gdzie działanie człowieka w świecie, stanowi życie wewnątrz tajemnicy nakierowane na zbawczą propozycję Boga i możliwość przeżywania Jego obecności w obrębie tego, co moje własne.

${ }^{47}$ F. Nietzsche, Tako rzecze Zaratustra, thum. W. Berent, Poznań 1995, s. 13.

${ }^{48}$ Fakt ten wyjaśnia L. Wittgenstein w Traktacie logiczno-filozoficznym: „Moglibyśmy je znać tylko wtedy, gdyby przyczynowość była koniecznością wewnętrzną, jak konieczność wniosku logicznego. Związek wiedzy z tym, co się wie, jest związkiem konieczności logicznej” (L. Wittgenstein, Tractatus Logico - Philosophicus, tłum. B. Wolniewicz, Warszawa 2000, s. 44).

${ }^{49}$ Wzajemną relację Boga i wolności stworzenia tak wyjaśnia Walter Kasper: „Ludzka wolność urzeczywistnia się i wypełnia dopiero przez teonomię, przez uznanie Boga i przez wspólnotę z Bogiem. Do wolności człowieka należy bowiem otwartość na nieskończoną tajemnicę". Por. $A u-$ tonomie und Theonomie. Zur Ortsbestimmung des Christentums in der modernen Welt, w: D. Mieth, H. Weber, Anspruch der Wirklichkeit und christlicher Glaube. Probleme und Wege theologischer Ethik heute, Düsseldorf 1980, s. 29. 


\section{CZłOWIEK JAKO BYT RELACYJNY}

Relacyjny charakter aktywności, jakie charakteryzują człowieka jako byt otwarty na drugiego i na to, co obecne w stworzeniu, rozumianym tu jako wszystko to, co stanowi zbiór bytów współistniejących „obok” oraz w sposobie doświadczania interpretacji tego, co się wydarzyło i wydarza, ujawnia odniesienie człowieka do Tajemnicy, do wolności wraz z odpowiedzialnością, do zastanej i współtworzonej struktury społecznej (religijno-społecznej) i do identyfikacji tego, który się ujawnia z tym, w jaki sposób istnieje w świecie. Relacyjność człowieka jako bytu otwartego na to, co inne względem niego, ale i na siebie samego, stawia pytanie o wolność samego człowieka i wolność tego, z którym się spotyka lub zostaje spotkany. W tle relacji, w których człowiek wykazuje swoją aktywność psycho-fizyczno-duchowa, rozbrzmiewa w końcu pytanie o stosunek wolności człowieka do wolności Tajemnicy, pozostającej w obrębie doświadczenia osobowego. Spotkanie człowieka z Bogiem w obrębie ściśle określonej przestrzeni i czasu nigdy nie dokonuje się wprost. Znaczy to, że nic, co może być spotkane w tym świecie, nie jest tożsame z Bogiem i Boga nie wyczerpuje. Tym samym spotkanie człowieka ze światem, z innymi nie wyczerpuje pragnienia spotkania $B_{0 g a}{ }^{50}$, dynamizując tym samym możliwość otwarcia człowieka na to, co pozostaje w zasięgu możliwości doświadczenia i domaga się uruchomienia procesów porządkujących, tzn. takich, w których jest budowana hierarchia ważności tego, co ważne dla niego samego i co wyrywa człowieka z zamknięcia na to, co inne i stawia go w sytuacji otwartości bytu jako poszukiwacza ostatecznego sensu tego, co jest.

Pytanie o relacyjny charakter człowieka, o wolność, domaga się zwrócenia uwagi na granice stosunków, w których dokonuje się swego rodzaju sprzężenie zwrotne między człowiekiem a tym, co obce wobec niego, w końcu o granicę spotykających się wolności, szczególnie pytanie o granice wolności człowieka względem Boga. Idąc dalej tym tropem należy zapytać o warunki dwóch wzajemnie spotykających się wolności, spotkania człowieka jako tego, który jest radykalnie różny od Boga (z uwzględnieniem bezwzględnej zależności od Niego jako Stwórcy) z Bogiem samym. Dążąc do rozumienia tej szczególnej relacji należy zwrócić uwagę na dążenia wolitywno-emocjonalne człowieka jako osoby duchowej, stanowiącej realny symbol afirmujący byt absolutny, jako podstawę widzianą w optyce tajemnicy ${ }^{51}$. Dana niepojmowal-

${ }^{50}$ Por. Tomasz z Akwinu, Traktat o Bogu, thum. G. Kurylewicz, Z. Nerczuk, M. Olszewski, Kraków 1999, s. 589-608.

${ }^{51}$ Widoczna jest tu zbieżność z poglądami Ernsta Cassirera, który w ramach określonej teorii kultury pojmuje człowieka jako animal symbolicum. Posługuje się on neokantowskim rozumieniem 
na rzeczywistość stanowi horyzont każdego duchowego spotkania z innymi wymiarami doświadczanego świata ${ }^{52}$. Ma tu miejsce rozróżnienie ontologiczne na podmiot będący radykalnie różny od owej niepojmowalnej rzeczywistości, będącej przestrzenią duchowego spotkania. Ale także na poziomie ontologicznym, oprócz tego rozróżnienia można mówić o rozdzielności w każdym procesie poznania, w którym nigdy poznawany przedmiot nie jest tożsamy z poznającym podmiotem. Mając na uwadze poczynione uwagi można na ich podstawie wnioskować o swoistej aporii, jakiej człowiek doświadcza w sytuacji mówienia o doświadczeniu tajemnicy ${ }^{53}$.

Owa aporia wynika $\mathrm{z}$ istoty samego spotkania bytu absolutnego i nieskończonego z bytem będącym radykalnie różnym, a jej owocem jest niemożliwość podejmowania pojęciowej refleksji, jako próby charakterystyki owego spotkania $^{54}$. Owa trudność uzasadnia twierdzenie mówiące o rozróżnieniu człowieka i Boga, jako dwóch różnych bytów. To dodatkowo wzmacnia postawioną tezę o dwóch wzajemnie dopełniających się w spotkaniu wolnościach na gruncie przed-ujęcia transcendencji ducha ${ }^{55}$, pod warunkiem stałej nieprzerwanej zależności świata od Boga, tak że świat stworzony w całym wymiarze jego trwania - a więc mając na uwadze historię, chwilę teraźniejszą i to, co przyszłe - wskazuje na to, co absolutne jako na swoją podstawę, nie znosząc przy tym wolności, w jaką jest wyposażone stworzenie ${ }^{56}$. Pytanie o moc działania Boga w stosunku do tego, co istnieje, a raczej do tego, co rozpoczęło swoje istnienie, dodatkowo wzmacnia pytanie o przed-ustanowiony porządek i o stosunek owego przed-ustanowienia do stworzenia z niczego.

symbolu, który stanowi rezultat wewnętrznej (apriorycznej) aktywności podmiotu, stanowiący nieodwracalny proces odchodzenia od świata „samego w sobie” w kierunku ludzkiej autonomii. Język, religia, kultura, nauka, stanowią strukturę symboliczną, poprzez które i ponad którymi człowiek dociera do rzeczywistości. (Por. E. Cassirer, Symbol i język, thum. B. Andrzejewski, Poznań 1995).

${ }^{52}$ Por. K. Rahner, Podstawowy wyktad wiary, s. 68.

${ }^{53}$ Kuc L., Zagadnienie antropologii chrześcijańskiej, „Studia Theologica Varsoviensia” 9 (1971), n. 2, s. 95-109.

${ }^{54}$ Zdaje się dlatego, że problem Boga w myśli współczesnych filozofów został zepchnięty na drugi plan. Przykładem może tu być dzieło Sein und Zeit Martina Heideggera. Heidegger mówi z wielkim dystansem o idei Bożego obrazu w człowieku, jednak jego myśl dąży konsekwentnie ku budowaniu idei właściwej możliwości bycia całościq jestestwa. Czy oznacza to, że odtąd człowiek to konstrukcja samowystarczalna, która odziedziczyła przymioty, przedtem odnoszące się do tego, co boskie? Czy odtąd pozostaje sam człowiek zamknięty w przestrzeni oddziaływania własnego sumienia zredukowanego do właściwego siebie bytu?

${ }^{55}$ Por. K. Rahner, Podstawowy wyktad wiary, s. 68.

${ }^{56}$ Ten szczególny związek teologia chrześcijańska zwykła nazywać stworzeniem, stworzonością świata. Rahner dodatkowo wskazuje na stałe bycie-obdarzonym-samym-sobą na mocy wolnego ustanowienia przez Boga osobowego. 
Creatio ex nihilo oznacza tu totalne działanie Absolutu, polegające na budowaniu zależności świata od Niego, przy zachowaniu niezależności Absolutu od świata ${ }^{57}$. Taki sposób rozumienia znosi tradycyjny schemat myślowy oparty na algorytmie przyczyna-skutek, w próbie usprawiedliwienia wszechświata, jego początku i konsekwencji zaistnienia ${ }^{58}$. W relacji Absolut-stworzenie mamy do czynienia z jednej strony z zależnością, a z drugiej autentycznością bytu jako takiego, która jest sposobem aktywnego wyjścia-z-samego-siebie. Bóg stwarza świat jako coś odrębnego, niebędącego Nim samym, ale stwarzając pozostawia go u siebie jako tego, który jest ugruntowany i w tej samej mierze wyzwala byt do samodzielności ${ }^{59}$. Samodzielność w kontekście relacji do Tajemnicy oznacza tu ciągłość bycia sobą, zdolność do istnienia zindywidualizowanego, pozwalającego na odkrycie tego, co rozumiemy poprzez czasowe trwanie człowieka w kontekście możliwości wiecznego trwania bytu.

Kolejnym zagrożeniem odgraniczającym relacyjny charakter człowieka od pojęcia wolności może być koncepcja ewolucji ${ }^{60}$, tak silnie obecna w sposobie myślenia dzisiejszego świata. Nawet teoria oparta na myśli Darwina, nie wykluczająca możliwości istnienia Boga jako tego, który nadaje przyrodzie określony projekt, realizujący się w czasie, ma pewne ograniczenia. Do fundamen-

${ }^{57}$ Por. tamże, s. 69.

${ }^{58}$ Tamże s. 89: „Wszędzie, gdzie natrafiamy na związek przyczynowy typu kategorialnego, wewnątrzświatowego, skutek jest wprawdzie na mocy swego pojęcia zależny od swojej przyczyny, ale owa przyczyna sama jest w szczególny sposób zależna także od swojego skutku, ponieważ nie mogłaby być przyczyna, gdyby nie doprowadziła do skutku. Nie jest tak w przypadku relacji między Bogiem a stworzeniem, ponieważ gdyby tak było, Bóg byłby ze swojej strony momentem wewnątrz sfery naszego doświadczenia kategorialnego, a nie absolutnym „dokąd” transcendencji, wewnątrz której poznajemy to, co indywidualne i skończone".

${ }^{59}$ Por. K. Rahner, Podstawowy wyktad wiary, s. 70.

${ }^{60}$ Postrzeganie człowieka wyłącznie na poziomie biologii niesie ze sobą zagrożenie, polegające na ujmowaniu istnienia w ramach paradygmatu ,ewolucyjnego”, gdzie podmiot stopniowo rozwija i wyłania z siebie właściwy sobie cel. W relacji do Boga człowiek podlega immanentnemu spełnieniu bycia, które następnie może zostać dopełnione spełnieniem o charakterze transcendentnym (zewnętrznym w stosunku do podmiotu, lecz dokonującym się w jego obrębie). Problem stanowi wyjaśnienie dopełnienia spełnienia immanentnego spełnieniem transcendentnym, w jaki sposób mówić o spełnieniu transcendentnym, ażeby mówić o człowieku jako fundamencie tego spełnienia i o samym spełnieniu - czym ono właściwie jest wobec możliwości pomieszania znaczeń pomiędzy immanentnym i transcendentnym spełnieniem człowieka. Podstawowa możliwość błędu w takim ujmowaniu człowieka polega na redukcji jego transcendencji do kategorialnej przyszłości człowieka jako bytu ewoluującego, dążącego do spełnienia i ujmowaniu jej w kategoriach spełnienia o ściśle wyznaczonych granicach, co stanowiłoby o immanencji, a nie transcendencji człowieka. Z drugiej strony tak zarysowany problem stawia pytanie o możliwość osiagnięcia spełnienia człowieka jako bytu cielesno-duchowego, ujmowanego jako całość, z niemożliwością spełnienia w aspekcie materialności człowieka - samodzielnego spełniania, co stanowi o problemie ujmowania stosunku ducha i materii, jej wolności stawania się, wobec Boga. Na ten temat por. K. Rahner, Pisma wybrane, t. II, tłum. G. Bubel, Kraków 2007, s. 122. 
talnego ograniczenia należy możliwość negacji celowościowej interpretacji procesów stawania się tego, co nas otacza. Rozwiązaniem powyższej aporii zdaje się być wprowadzony przez Rahnera termin samotranscendencji, występującej $\mathrm{z}$ ukrytym w tle pojęciem samoorganizacji ${ }^{61}$. Sposób rozumowania proponowany przez Rahnera dotyczy odkrywania tego, co nowe w stosunku do tego, co było uprzednio dane. Zakłada to istnienie siły, która absolutnie od niczego nie zależy, a którą zwykliśmy nazywać Bogiem. Tejże siły nie możemy nazywać, w kontekście poczynionych uwag dotyczących celowości i jej możliwości negacji, przyczyną lub jedną z wielu przyczyn oddziaływującej z zewnątrz w stosunku do tego, co jest, ze względu na transcendencję Boga. Gdybyśmy postawili działanie Boga w świecie w szeregu z innymi przyczynami wpływającymi na kształt świata, to łatwo można by wykazać pasywność działania tego, co nowe w stosunku do tego, co już było dane. Działanie Boga w stosunku do człowieka i otoczenia, w którym człowiek żyje, należy ujmować w kategoriach możliwości przekraczania samego siebie, tego, co uprzednio było dane. Egzemplifikacją procesu samotranscendencji jest choćby powstanie życia z materii nieorganicznej, stawanie się ludzkiej świadomości z tego, co już uprzednio dane było w zwierzętach ${ }^{62}$, prawdziwe rodzicielstwo matki i ojca także w odniesieniu do duszy poczętego dziecka ${ }^{63}$, ale także przekraczanie samego siebie, zamkniętego człowieka w akcie miłości, gdzie następuje otwarcie na to, co inne w stosunku do doświadczającego miłości człowieka ${ }^{64}$. Kolejnym egzystencjałem, będącym przejawem samotranscendencji, może być przemiana człowieka dokonująca się w byciu-ku-śmierci (sein-zum-Tode), jako dochodzeniu do kresu, ze świadomością i akceptacją ujawniania się „ukrytości” przychodzącej z zewnątrz śmierci. Przyglądając się temu, co dzieje się z dzisiejszą myślą o Bogu, jej oddaleniu od fizyki i biologii, można wnioskować, że próby rozumienia teorii samotranscendencji jako próby uchwycenia tego, co „nowe”, mogą prowadzić do odmiennych wskazań, dokonanych na gruncie teologii, jak i nauk szczegółowych ${ }^{65}$, jako dwóch różnych od siebie analiz przyczyn jednego i tego samego zdarzenia. Stąd potrzeba ponownego namysłu nad relacyjnością pod-

${ }^{61}$ Por. T. Kucia, Filozofia Biogenezy, Londyn 1981, s. 90-113.

${ }^{62} \mathrm{Ze}$ wskazaniem na proces hominizacji, z uwzględnieniem uwagi dotyczącej nieoczywistości dynamizmu stawania się jedności duszy i ciała.

${ }^{63}$ Warto zwrócić uwagę na transcendujący charakter relacji pomiędzy mężem a żoną i rodzicami a dzieckiem, stanowiącą być może, pierwszą i podstawową formę „otwarcia” osobowego na świat.

${ }^{64}$ Zagadnienie miłości stanowi przedmiot analiz podejmowanych przez św. Tomasza (STh. I-II, q. 26-28). Akwinata w powyższym tekście docieka spraw dotyczących natury miłości, jej przyczyn i skutków.

${ }^{65}$ „Teologia chrześcijańska chyba od zawsze była rozdarta pomiędzy dwiema tendencjami: $\mathrm{z}$ jednej strony wierność źródłom, z drugiej strony próba dogonienia współczesności. [...] Elemen- 
stawy do wewnątrzświatowych przyczyn, by uniknąć wspomnianych wyżej sytuacji $^{66}$.

Pomimo tej trudności Rahner wskazuje, że nie pozostaje nic innego jak tylko widzenie człowieka, jako bytu relacyjnego, wraz z całą historią wolności ${ }^{67}$. Historią wolności wraz z wpisaną w nią dynamiką relacji Bóg-człowiek, w której Bóg umieszcza człowieka w swojej własnej rzeczywistości, nie pozbawiając go wolności w relacji do Niego samego ${ }^{68}$. Nie znaczy to, że mamy do czynienia $\mathrm{z}$ dwoma wykluczającymi się wolnościami, na zasadzie włączenia jednej $\mathrm{w}$ drugą. Znaczy to tyle, że mamy do czynienia $\mathrm{z}$ jedyną $\mathrm{w}$ swoim rodzaju historia, która jest $\mathrm{w}$ pełni zindywidualizowana i wynikająca $\mathrm{z}$ faktu wolności człowieka. To, co dokonuje się w spotkaniu obydwu wolności, Rahner wyraził jako „rozszerzone w czasie wydarzenie stawania się tego, co ostateczne" ${ }^{" 9}$. Jest to historia rzeczywista, która, „trwa i dąży do ostatecznego celu, który dopiero nadejdzie" ${ }^{70}$. Każda indywidualna historia wolności zawiera w sobie odniesienie do przeszłości, teraźniejszości i moment projekcji w stronę przyszłości, dzięki temu stając się realnym odniesieniem do historii samego Boga, zawierającym moment samego pojęcia Boga.

\section{SUMMARY}

The anthropological turn is one of the main issues in the work of Karl Rahner. The issue tries to find an answer to the question who is man, in the context of the possibility of identifying him as a transcendent being, as a spiritual-personal being connected necessarily to the divine world, that experiences i. a. freedom and responsibility, the components of a set of categories of the human being.

\section{Key words:}

„Anthropological turn”, supernatural existential, transcendental experience, Karl Rahner, human transcendentality, freedom

\footnotetext{
ty aktualnego obrazu świata w rozmaitych ujęciach teologicznych muszą raczej wypierać pozostałości arystotelesowskiej kosmologii niż zmagać się z mechanicystycznym obrazem. Zresztą obecność aktualnego obrazu świata w teologii jest raczej niewielka. Poza stosunkowo częstymi nawiązywaniami do ewolucyjnej wizji świata Teilharda de Chardin, teologowie prowadzą raczej niechętnie autentyczny dialog z naukami. Zwracam tu uwagę na słowo ,autentyczny”, gdyż deklaracji jest wiele" (M. Heller, Naukowy obraz świata, w: Obrazy świata $w$ teologii $i$ w naukach przyrodniczych, Tarnów 1996, s. 13-14).

${ }^{66}$ Por. H. Vorgimler, Samotranscendencja, w: Nowy leksykon teologiczny, s. 327.

${ }^{67}$ K. Rahner, Pisma wybrane, t. I, tłum. G. Bubel, Kraków 2005, s. 164.

${ }^{68}$ I. Bokwa, Relacja chrystologii i antropologii jako model interpretacyjny teologii Karla Rahnera, „Studia Theologica Varsoviensia” 31 (1993), n. 2, s. 27-37.

${ }^{69}$ K. Rahner, Pisma wybrane, t. I, s. 164.

${ }^{70}$ Tamże.
} 